\title{
PENINGKATAN PERTUMBUHAN TANAMAN JAGUNG ( Zea mays L.) MENGGUNAKAN JAMUR MIKORIZA ARBUSKULAR DARI JENIS YANG BERBEDA PADA KONDISI CEKAMAN AIR
}

\section{Improvement Of Corn Growth (Zea mays L.) Using Arbuscular Mikoriza Fungus From Different Types In Different Water Conditions}

\author{
Isna ${ }^{1^{*}}$, Wahyu Harso ${ }^{1}$, dan Yusran ${ }^{2}$ \\ 1 Jurusan Biologi Fakultas Matematika dan Ilmu Pengetahuan Alam Universitas Tadulako Tondo Palu, \\ Sulawesi Tengah 94118 \\ 2 Jurusan Kehutanan Fakultas Kehutanan Universitas Tadulako Tondo Palu, Sulawesi Tengah 94118
}

Keywords:

Glomus, maize plant, growth.

\begin{abstract}
Arbsucular mycorrhizal fungi promote plant growth by enhancing mineral uptake. Contribution degree of arbuscular mycorrhizal fungi to promote plant growth depend on species of plant-fungus association. The aim of this study was to compare the ability of three species of Glomus to promote maize plant growth. Maize plants were inoculated with $20 \mathrm{~g}$ inoculum of either Glomus deserticola, Glomus etunicatum, or Glomus clorum. Inoculum was soil containing spore, hyphae and infected root. Maize plants without addition inoculum were also used as a control. Water availability in the soil as growing medium was maintained on $40 \%$ field capacity. The results showed that addition of inoculum from three species of Glomus increased average of maize plant shoot dry weight although there was no statisticaly significant differences. Maize plant inoculated with $G$. clorum had higher shoot dry weight than maize plant inoculated either with $G$. etunicatum or $G$. deserticola while root colonization by $\mathrm{G}$. clorum was lowest.
\end{abstract}

Kata Kunci:

Glomus, Tanaman

Jagung, Pertumbuhan.

\begin{abstract}
ABSTRAK
Jamur mikoriza arbukular meningkatkan pertumbuhan tanaman dengan meningkatkan penyerapan mineral. Tingkat kontribusi jamur mikoriza arbuskular untuk meningkatkan pertumbuhan tanaman tergantung pada spesies asosiasi jamur-tanaman. Tujuan dari penelitian ini adalah untuk membandingkan kemampuan tiga spesies Glomus untuk mempromosikan pertumbuhan tanaman jagung. Tanaman jagung diinokulasi dengan $20 \mathrm{~g}$ inokulum Glomus deserticola, Glomus etunicatum, atau Glomus clorum. Inokulum adalah tanah yang mengandung spora, hifa dan akar yang terinfeksi. Tanaman jagung tanpa penambahan inokulum juga digunakan sebagai kontrol. Ketersediaan air di tanah sebagai media tumbuh dipertahankan pada kapasitas lapangan $40 \%$. Hasil penelitian menunjukkan bahwa penambahan inokulum dari tiga spesies Glomus meningkatkan rata-rata bobot kering pucuk tanaman jagung walaupun tidak ada perbedaan yang signifikan secara statistik. Tanaman jagung yang diinokulasi dengan $G$. clorum memiliki bobot kering pucuk yang lebih tinggi daripada tanaman jagung yang diinokulasi dengan $G$. etunicatum atau $G$. deserticola sedangkan kolonisasi akar oleh $G$. clorum paling rendah
\end{abstract}

Corresponding Author: isna40114011@gmail.com 


\section{PENDAHULUAN}

Jagung (Zea mays L.) merupakan bahan pangan utama setelah beras dimana jagung mengandung karbohidrat yang tinggi. Beberapa daerah di Indonesia memanfaatkan jagung sebagai bahan makanan pokok selain beras. Potensi pemasaran jagung juga terus mengalami peningkatan hal ini terjadi karena semakin banyaknya permintaan jagung sebagai campuran pakan ternak serta bahan pangan (Indriati dkk., 2013). Produksi jagung perlu dikembangkan sebagai bahan pangan untuk memenuhi kebutuhan masyarakat. Peningkatan produksi jagung di Indonesia terus diupayakan pemerintah dalam rangka memenuhi kebutuhan dalam negeri terutama untuk pangan dan pakan (Safuan dan Hadini, 2012).

Jamur Mikoriza Arbuskular (JMA) merupakan jamur akar yang bersimbiosis dengan mayoritas tumbuhan tingkat tinggi dan umumnya ditemukan pada ekosistem terestrial (Smith and Read, 2008). Simbiosis

\section{BAHAN DAN METODE}

Penelitian ini dilaksanakan pada bulan April - September 2018 di Hortus dan Laboratorium Bioteknologi Jurusan Biologi Fakultas Matematika dan IImu Pengetahuan Alam dan Laboratorium IImu Tanah Fakultas Pertanian Universitas Tadulako. tersebut dapat bermanfaat bagi tanaman melalui beberapa cara diantaranya peningkatan serapan hara khususnya $P$ (Smith and Read, 2008), perbaikan status air dan perlindungan tanaman terhadap cekaman lingkungan berupa kekeringan (Auge, 2004), cemaran logam berat (Husna, 2010), salinitas (Al-Karaki, 2006), patogen (Akhtar and Siddiqui, 2008), genangan (Fougnies et al., 2007) dan perbaikan struktur tanah (Nichols, 2008). Peran tersebut sangat dikaitkan dengan pembentukan struktur JMA baik di dalam akar maupun di luar akar tanaman (Smith dan Read, 2008).

Berdasarkan penelitian Lapanjang (2011), efektivitas JMA jenis glomus sp yang diinokulasi denga jarak pagar pada cekaman kekeringan dengan pemberian kadar air $80 \%$ dan $40 \%$, dimana JMA jenis glomus sp dapat meningkatkan bobot basah akar, bobot kering batang, bobot kering daun dan tinggi tanaman jarak pagar.

\section{Bahan}

Bahan yang digunakan adalah benih jagung (Zea mays L.), tanah, Inokulum jenis Glomus deserticola, Glomus etunikatum dan Glomus clorum, 1\% sodium hipoclorait (NaOCl)/ Baycline, Tryphan Blue, $10 \%$ $\mathrm{KOH}$, asam laktat, $2 \mathrm{~N} \mathrm{HCl}$, aquadest, $\mathrm{H}_{2} \mathrm{O}_{2}$, $\mathrm{H}_{2} \mathrm{SO}_{4}$ pekat, Amonium Molibdat, Kalium 
Antimonil Tratrat, Asam Askorbat dan $\mathrm{KH}_{2} \mathrm{PO}_{4}$, Urea, $\mathrm{KCl}$, polybag, spidol, karet, plastik tahan panas, lakban, tissue dan label.

\section{Prosedur Penelitian}

Penelitian ini dilaksanakan dengan menggunakan metode Rancangan Acak Lengkap (RAL) tampa mikoriiza dan diinokulasi mikoriza dengan 4 perlakuan dan 4 kali ulangan

\section{a. Penyiapan media tumbuh}

Diambil tanah dari lapisan permukaan tanah hingga kedalaman 20 $\mathrm{cm}$, dicampur hingga merata, dikeringanginkan selama 2 hari, kemudian diayak dengan saringan berukuran $4 \mathrm{~mm}$ agar tanahnya homogen. Tanah dimasukkan kedalam plastik tahan panas, disterilkan dengan menggunakan oven pada suhu $80^{\circ} \mathrm{C}$ selama 48 jam. Setelah disterilisasi, didinginkan pada suhu ruang selama $1 \times 24$ jam sebelum digunakan. Tanah yang telah dingin dimasukkan kedalam polybag berukuran $25 \mathrm{~cm} \times 30 \mathrm{~cm}$.

\section{b. Penentuan kapasitas lapang tanah}

Diambil sebanyak 500 gram tanah yang telah dikeringkan dengan oven. Tanah dimasukkan pada wadah yang memiliki lubang pada bagian alasnya. Dimasukan air ke dalam wadah hingga air tersebut mengenangi wadah (jenuh) kemudian didiamkan selama $2 \times 24$ jam. Air yang ditambahkan dan air yang jatuh dari wadah diukur volumenya. Jumlah air kapasitas lapang pada tanah tersebut merupakan jumlah air yang dimasukan pada wadah diku rang dengan jumlah air yang menetes pada wadah penampung. Air yang terikat dalam tanah ditetapkan sebagai $100 \%$ kapasitas lapang. Kadar air tanah dapat ditentukan dengan rumus

$$
\mathrm{W}=\frac{(\mathrm{TB}-\mathrm{TK})}{\mathrm{TK}} \times 100 \%
$$

Keterangan :

W : Kadar air tanah

TB : Berat basah tanah

TK : Berat kering tanah

\section{c. Penyiapan benih}

Biji jagung direndam dengan air diperhatikan keutuhan seluruh permukaan biji. Biji yang melayang diatas permukaan air dibuang dan biji yang tenggelam serta memiliki permukaan yang utuh diambil dijadikan sebagai benih. Biji yang telah diseleksi disterilisasi dengan merendam biji di dalam larutan $1 \%$ Sodium hypoclorite (NaOCl) / Baycline selama 10 menit. Lalu dicuci dengan air sampai bersih.

d. Pemupukan dan inokulasi jamur mikoriza arbuskular

Tanah sebanyak $5 \mathrm{~kg}$ dipupuk dengan urea dan $\mathrm{KCl}$ sebanyak 0,4 dan $0,3 \mathrm{~g} / \mathrm{kg}$ tanah kering serta diinokulasikan dengan jamur mikoriza arbsuskula sebanyak 20 gram kemudian dicampur secara homogen. 


\section{e. Penanaman}

Benih kemudian ditanam pada media tumbuh tanah dalam polybag berukuran $25 \mathrm{~cm} \times 30 \mathrm{~cm}$ dengan kedalaman tanam 2-3 cm dari atas permukaan sebanyak 3 lubang sesuai banyaknya benih yang akan ditanam. Benih yang telah ditanam diberi air sampai kandungan air mencapai kapasitas lapang, kemudian polybag diletakkan dalam rumah plastik. Setelah benih berumur satu minggu dipilih satu benih yang memiliki tingkat keseragaman tinggi pada masing-masing pot. Dua benih lainnya dimatikan dengan cara memotong benih pada bagian pangkal batangnya.

\section{f. Pemeliharaan}

Kandungan air pada kapasitas lapang dipertahankan sampai tanaman

\section{HASIL / RESULT}

\section{a. Berat segar tajuk tanaman.}

Hasil analisis statistik menunjukkan bahwa pemberian inokulum jamur mikoriza arbuskula dari ketiga jenis Glomus tidak berpengaruh nyata terhadap berat segar tajuk tanaman jagung. Akan tetapi ada kecenderungan adanya pemberian inokulum dari ketiga jenis genus meningkatkan berat segar tanaman jagung. Tanaman jagung yang diinokulasikan dengan $G$. clorum jagung berumur 2 minggu. Setelah umur 2 minggu air di dalam polybag dipertahankan sekitar $40 \%$ dari kapasitas lapangnya. Pemberian air dilakukan setiap tiga hari sekali. Jumlah air yang berkurang dihitung dengan cara gravimetrik. Peletakan pot secara acak bersamaa dengan waktu pemberian air. Tanaman dijaga dari gulma dan serangga dengan cara mencabut dan penyemprotan dengan insektisida bila diperlukan.

\section{g. Analisis data}

Data yang diperoleh kemudian dianalisis dengan analisis variasi dengan oneway anova menggunakan software SPSS. Selanjutnya bila analisis variasi menunjukkan perlakuan yang diberikan berpengaruh nyata maka dilakukan uji lanjut DMRT pada taraf uji 5\%.

cenderung memiliki berat segar tajuk yang lebih besar dibandingkan dari tanaman jagung yang diinokulasi dengan G. etunicatum ataupun G. deserticola (Gambar. 1)

\section{b. Berat kering tajuk}

Berat kering tajuk tanaman jagung tidak dipengaruhi oleh pemberian inokulum dari ketiga jenis Glomus. Berat kering cenderung lebih tinggi pada tanaman yang diinokulasi dengan jamur 
dari ketiga jenis Glomus yang digunakan meskipun tidak berbeda nyata. Tanaman jagung yang diinokulasi dengan $G$. clorum cenderung memiliki berat kering tajuk tanaman yang lebih tinggi dibandingkan $G$. etunicatum ataupun yang diinokulasi dengan $G$. deserticola (Gambar. 2).

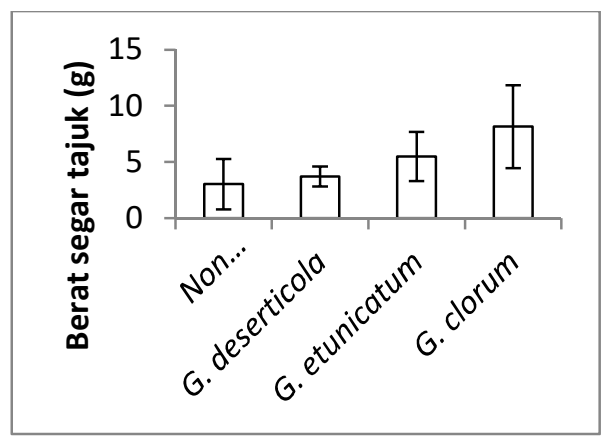

Gambar 1. Berat segar tanaman jagung umur 51 hari setelah tanam yang tidak diinokulasi (non mycorrhiza) dan yang diinokulasi oleh jamur arbuskula mikoriza dari jenis $G$. deserticola, G. etunicatum atau $G$. clorum. Data yang ditampilkan adalah nilai rata-rata \pm SD. One way Anova yang dilakukan dengan menggunakan taraf signifikansi 0,05.

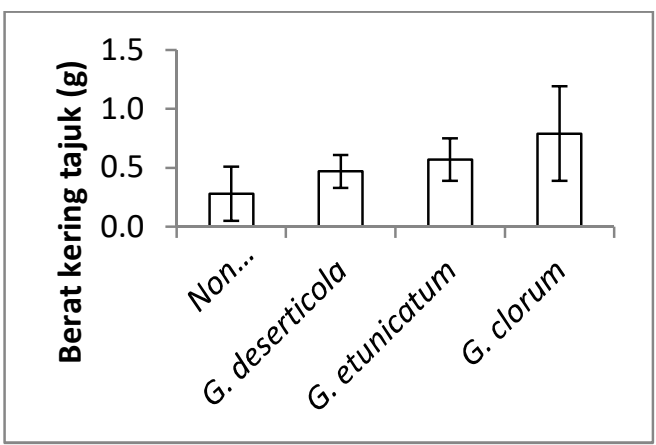

Gambar 2. Berat kering tanaman jagung umur 51 hari setelah tanam yang tidak diinokulasi (non mycorrhiza) dan yang diinokulasi oleh jamur arbuskula mikoriza dari jenis $G$. deserticola, G. etunicatum atau $G$. clorum. Data yang ditampilkan adalah nilai rata-rata $\pm S D$. One way Anova yang dilakukan dengan menggunakan taraf signifikansi 0,05 .

c. Berat segar akar

Berat segar akar tanaman jagung tidak dipengaruhi oleh pemberian inokulum jamur dari ketiga jenis Glomus. Tidak ada kecenderungan peningkatan berat segar akar tanaman jagung akibat pemberian inokulum (Gambar. 3).

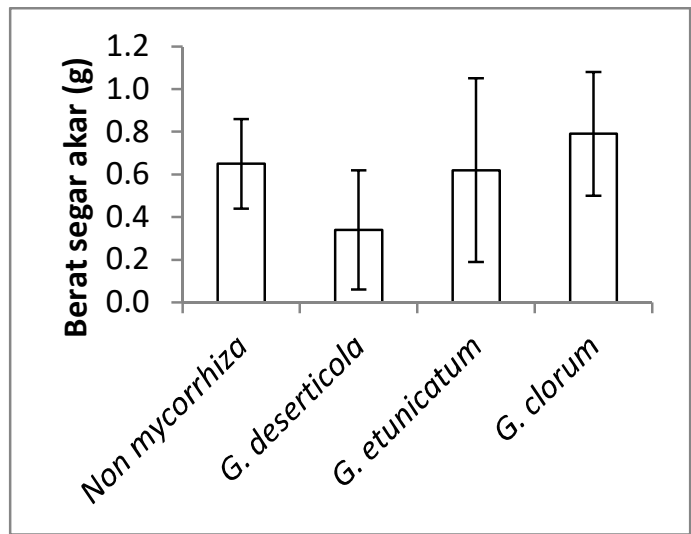

Gambar 3. Berat segar akar tanaman jagung umur 51 hari setelah tanam yang tidak diinokulasi (non mycorrhiza) dan yang diinokulasi oleh jamur arbuskula mikoriza dari jenis $G$. deserticola, G. etunicatum atau $G$. clorum. Data yang ditampilkan adalah nilai rata-rata $\pm S D$. One way Anova yang dilakukan dengan menggunakan taraf signifikansi 0,05 .

\section{d. Kadar P (fosfor) Tajuk}

Kandungan fosfor dalam jaringan tajuk tidak dipengaruhi oleh pemberian inokulum dari ketiga jenis Glomus. Inokulum jamur yang diberikan tidak meningkatkan kandungan fosfor dalam jaringan tajuk tanaman jagung (Gambar. 4). 


\section{e. Presentase akar yang terkolonisasi}

\section{mikoriza}

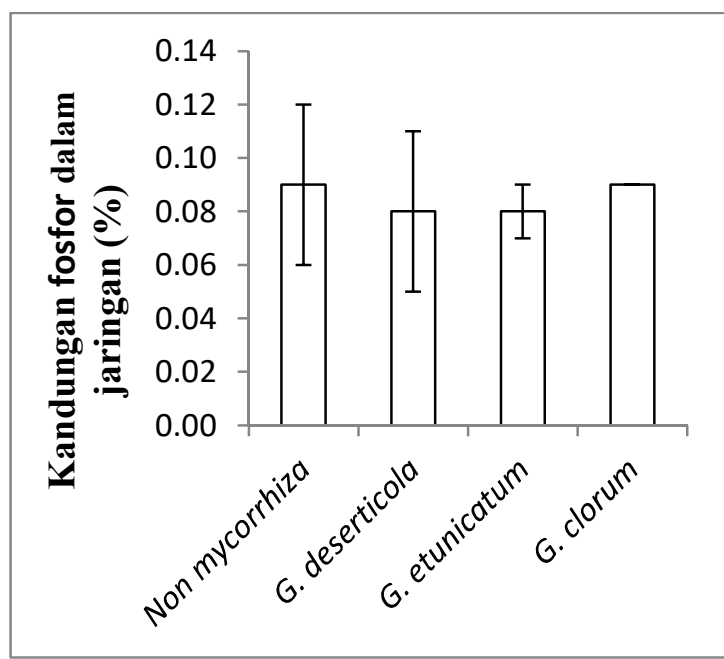

Gambar 4. Kandungan fosfor dalam jaringan tajuk tanaman jagung umur 51 hari setelah tanam yang tidak diinokulasi (non mycorrhiza) dan yang diinokulasi oleh jamur arbuskula mikoriza dari jenis $G$. deserticola, G. etunicatum atau G. clorum. Data yang ditampilkan adalah nilai rata-rata $\pm S D$. One way Anova yang dilakukan dengan menggunakan taraf signifikansi 0,05 .

Tingkat kolonisasi jamur terhadap akar tanaman jagung dipengaruhi oleh pemberian inokulum Glomus (Lampiran 1). Terdapat kontaminasi yang terjadi pada akar tanaman yang tidak diberi inokulum jamur mikoriza arbsukula. Akan tetapi persentase tingkat kolonisasinya masih lebih rendah dari akar tanaman jagung yang diinokulasi dengan ketiga jenis jamur Glomus. Akar tanaman yang diinokulasi dengan jamur mikoriza arbsukula memiliki kolonisasi yang lebih tinggi dibandingkan dengan akar tanaman yang tidak diinokulasi terutama pada $G$. deserticola dan G. etunicatum. Rerata kolonisasi dari G. clorum lebih rendah dibandingkan dengan $G$. deserticola dan G. etunicatum, dan lebih tinggi dari akar tanaman yang tidak diberi inokulum meskipun secara statistik tidak berbeda nyata (Gambar. 5)

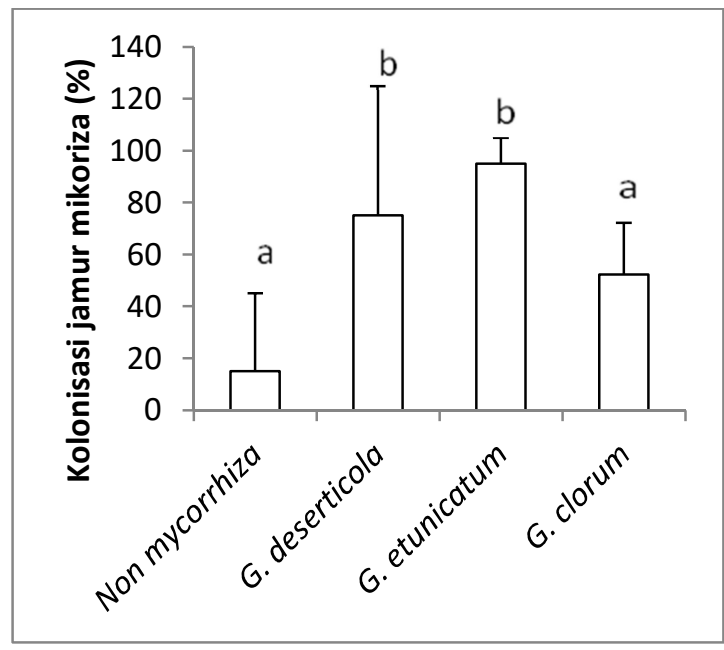

Gambar 5. Kolonisasi akar tanaman jagung umur 51 hari setelah tanam yang tidak diinokulasi (non mycorrhiza) dan yang diinokulasi oleh jamur arbuskula mikoriza dari jenis $G$. deserticola, G. etunicatum atau $G$. clorum. Data yang ditampilkan adalah nilai rata-rata \pm SD. Batang grafik yang diikuti oleh huruf yang sama menunjukkan tidak berbeda nyata $(P<0,05)$. 


\section{PEMBAHASAN}

Jamur Mikoriza Arbuskular merupakan jamur yang umumnya bersimbiosis pada tumbuhan tingkat tinggi dimana jamur mikoriza ini dapat membantu tumbuhan dalam proses pertumbuhan tanaman. Dari hasil penelitian menunjukan bahwa ketiga jenis jamur mikoriza arbuskular dari genus Glomus yang digunakan dapat meningkatkan rerata berat segar dan kering tajuk tanaman jagung (Gb. 1 dan 2) meskipun secara statistik tidak berbeda nyata dengan rerata berat kering tanaman jagung yang tidak diinokulasi dengan Glomus. Jamur mikoriza arbsukula meningkatkan pertumbuhan tanaman dengan cara membantu proses penyerapan unsur hara terutama $P$ (fosfor). Selain itu jamur mikoriza arbsukula juga dapat membantu penyerapa unsur hara lain seperti N (nitrogen), Zn (zing), $\mathrm{Cu}$ (tembaga), S (belerang) dan Mo (Molibdenum) (Trisilawati dkk., 2001). Pada penelitian ini kandungan fosfor dalam jaringan tajuk tidak dipengaruhi oleh pemberian inokulasi jamur mikoriza arbsukula dari genus Glomus pada media tumbuhnya (Gb. 4). Berat kering yang lebih tinggi pada tanaman jagung yang diinokulasi dengan Glomus dibandingkan dengan tanaman jagung yang tidak diinokulasi kemungkinan karena pertumbuhan tajuk yang lebih cepat bila dibandingkan dengan akumulasi fosfor (Jarrel and Beverly, 1981).

Berat segar akar tidak berbeda nyata antara tanaman jagung yang diinokulasi dengan yang tidak diinokulasi (Gb. 3). Pada penelitian ini berat kering akar tanaman tidak diukur karena berat segar akar yang didapat digunakan untuk menghitung prosentase kolonisasi akar oleh jamur mikoriza arbuskula. Demikian pula berat rasio antara tajuk dengan akar tidak bisa diukur.

Prosentase akar yang dikolonisasi oleh jamur mikoriza arbuskula dipengaruhi oleh pemberian inokulum. Kolonisasi jamur pada akar tanaman yang diinokulasi berbeda nyata dengan yang tidak diinokulasi (Gb. 5). Tingkat kolonisasi jamur arbsukula terhadap akar lebih tinggi pada akar tanaman yang diberi inokulum dibandingkan dengan yang tidak diberi inokulum. Terdapat kolonisasi jamur pada akar yang tidak diberi inokulum meskipun menggunakan tanah steril hal ini mungkin disebabkan oleh adanya kontaminasi. Tingkat kolonisasi jamur pada G. clorum memiliki rerata yang lebih rendah dibandingkan $G$. deserticola dan $G$. etunicatum. Namun demikian, tanaman yang diinokulasi dengan $G$. clorum memiliki rerata yang lebih tinggi dibanding dengan tanaman yang diinokulasi dengan $G$. deserticola atau G.etunicatum. perbedaan respon tanaman terhadap masing-masing jenis inokulum yang diberikan pada 
tanaman menunjuka tingkat efektivitas jamur mikoriza arbuskular dalam merangsang pertumbuhan masing-masing tanaman. Jamur mikoriza arbuskular tidak mepunyai inang yang spesifik, namun jenis tertentu dapat lebih merangsang pertumbuhan jenis tanaman tertentu dengan kata lain tingkat efektivitas suatu jenis jamur pembentuk jamur mikoriza arbuskular berbeda-beda terhadap jenis tanaman (Ulfa dkk, 2009).

\section{DAFTAR PUSTAKA}

Akhtar, M. S., and Siddiqui, Z. A. (2008). Arbuscular mycorrhizal fungi as potential bioprotectants against plant pathogens. In: Siddiqui ZA, Akhtar MS, Futai K (Eds.), Mycorrhizae sustainable agriculture and forestry (pp. 61-98). Springer, Dordrecht, The Netherlands.

Al-Karaki, G. N. (2006). Nursery inoculation of tomato with arbuscular mycorrhizal fungi and subsequent performance under irrigation with saline water. Scientia Horticulturae, 109, 1-7.

Auge, R. M. (2004). Arbuscular mycorrhizae and soil/plant water relations, canadian journal of soil science, 84, 373-381.

Fougnies, L., Renciot, S., Muller F., Plenchette C., Prin Y, defaria, S.M., Bouvet, J.M., Sylla, S. N. D., Dreyfus, B., and Ba, A. M. (2007). Arbuscular mycorrhizal colonization and nodulation improve flooding tolerance in Pterocarpus officinalis Jacq. seedlings. Mycorrhiza, (17), 159-166.
Jamur mikoriza arbsukula dapat meningkatkan pertumbuhan tanaman jagung. Kontribusi jamur mikoriza terhadap peningkatan pertumbuhan tanaman tergantung kepada jenis jamur dan tanaman inang. Glomus clorum lebih meningkatkan pertumbuhan tanaman jagung dibandingkan dengan Glomus deserticola dan Glomus etunicatum meskipun memiliki kolonisasi terhadap akar yang lebih rendah.

Husna. (2010). Pertumbuhan bibit kayu kuku (Pericopsis mooniana THW) melalui aplikasi fungi mikoriza arbuskula (FMA) dan ampas sagu pada media tanah bekas tambang nikel. Universitas Haluoleo, 9 (3). 131149.

Indriati, G., Ningsih, I. L., dan Rizki. (2013). Pengaruh pemberian fungi mikoriza multispora terhadap produksi tanaman jagung (Zea mays L.), Prosiding Semirata FMIPA Universitas Lampung. Hal 323-327.

Jerrell, W. N and Beverly, R. B. (i981). The dilution effect in pland nutrition studien. Departement of soil and environmental sciences. Advances in agronomy. university of calivorniariverside. Hal 197-224.

Lapanjang, I. M., Purwoko, B. S., Hariyadi., Wilarso, S., dan Melati, M. (2011). Efektivitas fungi mikoriza arbuskular dengan provenan jarak pagar pada cekaman kekeringan. Jurnal Agrotropika 16 (1), 29-37.

Nichols, K. A. (2008). Indirect contributions of $A M$ fungi and soil aggregation to plant growth and protection. In: Mycorrhizae: Sustainable Agriculture 
and Forestry. ZA Siddiqui, MS Akhtar and K Futai, (Eds), 177-194.

Safuan, O. L., dan Hadini H. (2012). Klasifikasi genotip jagung lokal asal kabupaten wakatobi dan kabupaten bombana berdasarkan karakter fenotipnya, jurnal agroteknos, 2 (3), 126-13.

Smith, S. E., and Read, D. J. (2008). Mycorrhizal Symbiosis. Third edition: Academic Press. Elsevier Ltd. New York, London, Burlington, San Diego.768 p.SUAMBA, I., at all, (2014), Isolasi dan Identifikasi Fungi Mikoriza Arbuskular (Fma) secara Mikroskopis pada Rhizosfer Tanaman Jeruk (Citrus sp.)
Trisilawati, O., Supriatun, T., dan Indrawati, I. (2001) Pengaruh Mikoriza Arbuskula dan Pupuk Fosfat Terhadap Pertumbuhan Jambu Mente pada Tanah Podsolik Merah Kuning, Jurusan Biologi, FMIPA UNPAD, Balai Penelitian Tanaman Rempah dan Obat. Bogor 3, (2), 9198.

Ulfa, M., Waluyo, E. A., dan Martin, E. (2009). Pengaruh inokulasi fungi mikoriza arbuskula Glomus clorum, Glomus etunicatum dan Gigaspora Sp. terhadap pertumbuhan semai mahoni san seru, Balai Penelitian Kehutanan Palembang, Jurnal Penelitian Hutan Tanaman, 6(5), 273 -280 . 